\title{
Влияние ферментов эксцизионной репарации оснований ДНК на активность АР-эндонуклеазы человека
}

\author{
Кладова О.А.*, Федорова О.С., Кузнецов Н.А. \\ Институт химической биологии и фундаментальной медицины СО РАН, Новосибирск, Россия \\ *e-mail: kladova@niboch.nsc.ru
}

Ключевые слова: эксцизионная репарация оснований, активность ферментов, полиморфизм

Мотивация и цель: Система эксцизионной репарации оснований (BER) представляет собой сложный многокомпонентный процесс, в котором поврежденная ДНК переносится от одного белка к другому. Известно, что некоторые участники BER способны оказывать влияние на активность друг друга. В данной работе изучали активность некоторых ферментов BER в экстрактах различных линий опухолевых клеток, а также провели исследование влияния ферментов репарации ДНК на активность АР-эндонуклеазы человека (APE1) и ее природных полиморфных вариантов (SNP).

Meтоды $и$ алгоритмы: Для определения активности ферментов репарации ДНК использовали короткие ДНК-зонды, содержащие флуоресцентные метки FAM/BHQ1 и поврежденный нуклеотид, обеспечивающий специфичность к определенному ферменту. Исследование активности ДНКгликозилаз и АР-эндонуклеазы проводили на культурах клеток HEK293T, A549, WT, 786-0, HeLa, HKC8 и MCF7. Регистрацию расщепления ДНК-зонда при взаимодействии с очищенным препаратом APE1 дикого типа и SNP вариантов, содержащих замены R221C, N222H, R237A, G241R, M270T, R274Q и P311S, проводили, используя спектрофлуориметр остановленного потока.

Pезультаты: При исследовании активности ферментов репарации ДНК в экстрактах опухолевых клеток было показано, что уровень активности ферментов репарации, взаимодействующих с ДНКзондами, содержащими АР-сайт, 5,6-дигидроуридин и уридин, был выше в раковых линиях по сравнению с нормальными клетками почки человека НКС8. При анализе белок-белкового влияния ферментов участников BER на APE1 дикого типа и SNP варианты, было показано, что мутантные формы АР-эндонуклеазы стимулируются по-разному. Установлено, что белки AAG, OGG1, Polß и XRCC1 значительно стимулировали WT APE1 и мутантные формы R237A и P311S. Незначительный эффект наблюдался для других полиморфных вариантов (R221C, N222H, G241R, M270T, R274Q), что указывает на то, что эти аминокислотные остатки могут участвовать в белокбелковых взаимодействиях при репарации повреждений. Интересно отметить, что UNG2 и PCNA незначительно стимулировали WT APE1, снижали активность R221C, M270T и R274Q и не оказывали влияния на N222H и G241R.

Заключение: Используя короткие ДНК-зонды был определен уровень активности некоторых ферментов BER в клеточных лизатах различных культур клеток, а также установлено влияние отдельных ДНК-гликозилаз и других белков репарации ДНК на активность АР-эндонуклеазы дикого типа и ее природных полиморфных вариантов.

Благодарности: Работа выполнена при поддержке гранта МД-3775.2019.4. 